\title{
Ground-Water Provinces of Brazil
}

GEOLOGICAL SURVEY WATER-SUPPLY PAPER 1663-A

Prepared in cooperation with the Government of Brazil and the United States Operations Mission to Brazil

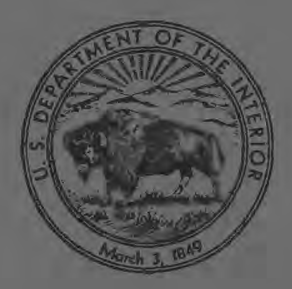




\section{Ground-Water Provinces of Brazil}

By ROBERT SCHNEIDER

CONTRIBUTIONS TO HYDROLOGY OF LATIN AMERICA AND THE ANTILLES

GEOLOGICAL SURVEY WATER-SUPPLY PAPER 1663-A

Prepared in cooperation with the

Government of Brazil and the United

States Operations Mission to Brazil

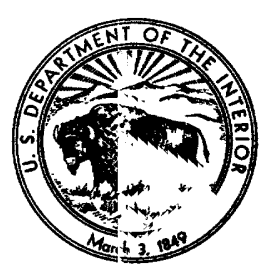




\section{UNITED STATES DEPARTMENT OF THE INTERIC STEWART L. UDALL, Secretary}

\section{GEOLOGICAL SURVEY}

Thomas B. Nolan, Director 


\section{CONTENTS}

\begin{tabular}{|c|c|}
\hline Abstract_. & A1 \\
\hline itroduction.. & 1 \\
\hline Geography & 3 \\
\hline Ground-water provinces. & 3 \\
\hline Coastal Plain province & 4 \\
\hline Eastern Precambrian province & 5 \\
\hline Central Precambrian province & 6 \\
\hline Northern Precambrian province & 7 \\
\hline Parnaíba-São Francisco Mesozoic and Paleozoic province........ & 7 \\
\hline Paraná Mesozoic and Paleozoic province & 9 \\
\hline Amazon province & 12 \\
\hline Ground-water problems & 12 \\
\hline Northeast Brazil & 13 \\
\hline São Paulo area & 14 \\
\hline elected references & 14 \\
\hline
\end{tabular}

\section{ILLUSTRATION}

Plate 1. Map of Brazil showing ground-water provinces_.......... In pocket. 


\title{
CONTRIBUTIONS TO HYDROLOGY OF LATIN AMERICA AND THE ANTILLES
}

\section{GROUND-WATER PROVINCES OF BRAZIL}

\section{By ROBERT SCHNEIDER}

\begin{abstract}
As part of a study of the status of investigations and development of ground water in Brazil, made under the auspices of the United States International Cooperation Administration and with the cooperation of the Govemment of Brazil, the country was divided into seven ground-water provinces. Tr o identification and delineation of the provinces were based on the regional distribution of the dominant geologic units which are known or inferred to have distinctive water-bearing characteristics.

Three of the provinces, covering most of the country, are underlain by Precambrian crystalline rocks. Three others coincide in part with four extensive sedimentary basins-the Parnaiba or Maranhão basin and the contiguous São Francisco basin in the northeast and east, the Amazon basin in the north snd northwest, and the Parana basin in the south and southwest. In addition, the narrow, discontinuous coastal plain is considered as a province. The occurrence of ground water is discussed briefly, and pertinent data are given on the more important aquifers, together with information on some existing wells.

Because of the widespread distribution of crystalline rocks of low permeability, it is difficult in many areas to develop large or even adequate gro'md-water supplies. In general, satisfactory supplies of water are available in most of the rest of the country. Some problems include the relative deficienc 7 of rainfall in the northeast together with the occurrence, in parts of this region, of mineralized water in the crystalline rocks. Also, there is a potential problem of excessive lowering of water levels and interference among wells in the intensively developed area of the city of são Paulo.
\end{abstract}

\section{INTRODUCTION}

As the result of a request by the Brazilian Serviço Especial de Saúde Pública (S.E.S.P.) to the United States Operations Mission to Brazil (International Cooperation Administration), the writer made a brief study early in 1960 of the status of ground-water investigations and related activities. S.E.S.P. is a federal public health agency, one of several national and state agencies concerned with the development of ground-water supplies. 
The general objectives of the study were: (a) to determine and evaluate the types of hydrogeologic data being collected and investigations being made, and (b) to determine the extent of the present ground-water development and of plans for future development. In the course of interviewing public officials, geologists, enginesrs, and well drillers, considerable data were collected on the genersl occurrence of ground water. On the basis of information obtained by reviewing the available published and unpublished information on geology and hydrology, and by making several field trips, it was possible to subdivide the country into ground-water provinces. The purpose of this report is to discuss briefly the occurrence of ground water in each of the provinces.

The study would not have been possible without the cooperation and guidance of Dr. Henrique Maia Penido, Superintendent of the S.E.S.P.; Eng. Guilherme Augusto Telles de Miranda, Direstor, Divisão de Engenharia of the S.E.S.P.; and Dr. James D. Wharton and Mr. James D. Williams, Chief-and Chief Sanitary Engineer, respectively, of the Health and Sanitation Division, U.S. Operations Mission to Brazil. Thanks are also due various engineers on the staff and in the field offices of the Divisão de Engenharia for their assistance. The writer would like to express special gratitude to Dr. Alberto Ribeiro Lamego, Director, Divisão de Geologia e Mineralogia, Departamento Nacional da Produção Mineral, for permission to use the original manuscript copy of his geologic map of Brazil (Lamego, 1960) in the preparation of the map of the ground-water provinces. Dr. Abrão Hausman, Chief Secção de Geologia e Poços, Comissão Especial de Obras de Irrigação, Estado do Rio Grande do Sul, was most cooperative in discussing and making available his unpublished monuscript of a report on ground-water possibilities in the state of Ric Grande do Sul.

Particularly helpful information and data on the geology and ground water were obtained through discussions with these persons:

Eng. Augusto Durante, Instituto Geográfico e Geológicc. Estado do São Paulo.

Dr. Wilhelm Kegel, Divisão de Geologia e Mineralogia, Departamento Nacional da Produção Mineral.

Dr. Viktor Leinz, Departamento de Geologia e Paleontologia, Universidade de São Paulo.

Dr. J. de Carvalho Lopes, Belo Horizonte, Minas Gerais.

Dr. Reinhard Maack, Serviço de Geologia do Instituto de Biologia e Pesquisas Tecnológicas, Estado do Paraná.

Eng. M. S. Sobrinha, Departamento da Produção Mineral, Estado do Rio Grande do Sul.

Dr. H. O. Sternberg, Centro de Pesquisas de Geografia c'o Brasil, Universidade do Brasil. 


\section{GEOGRAPHY}

Although Brazil extends from about lat $34^{\circ} \mathrm{S}$. to lat $5^{\circ} \mathrm{N}^{\top}$, it is almost entirely in the Tropic Zone. It is situated between long $35^{\circ}$ $\mathrm{W}$. and long $74^{\circ} \mathrm{W}$. and it covers $3,286,170$ square miles, an area larger than the conterminous United States (3,022,387 sq mi). According to various estimates the present population is about 65 million.

Most of the country is composed of gently rounded hills underlain by crystalline rocks. Low mountains occur where these rocks are more resistant to weathering; the highest mountain, located northeast of the city of Rio de Janeiro, has an altitude of about 9,460 feet above sea level.

Several extensive areas are underlain by sedimentary rocks; here the topography is generally subdued. These terranes may form broad plateaus or widespread lowlands, such as that of the Amazon valley. There is also a relatively narrow, discontinuous coastal plain composed of sedimentary strata.

The belt of crystalline-rock highlands commonly drops off sharply to the Atlantic Ocean in the southern part of the country. North of about lat $13^{\circ} \mathrm{S}$. there is a gradual rise from the coast to the interior.

In general, Brazil receives an abundance of precipitation, although it is not equitably distributed geographically or in time. The following areas receive averages of between 80 and 135 inches of rsin annually: (a) the upper Amazon lowlands; (b) an area along the coast north of Belém (lat $1^{\circ} \mathrm{S}$.) ; (c) a few scattered places on the coastal escarpment in the southeast; $(d)$ the mountain summits of the southeast; (e) a small area in the western part of the state of Paraná; and (f) a small area in the northwestern part of the state of Minas Gerais. Only a small part of northeastern Brazil is relatively deficient in rainfall. In most of this region rainfall averages between 20 and 25 inches yearly but there are small areas that receive an annual average of less than 10 inches. The problem of irregular distribution of rainfall is best exemplified in the northeast where, in certain places during the period 1835-1935, floods or droughts were recorded more than 50 times (James, 1960, p. 362).

\section{GROUND-WATER PROVINCES}

In view of the fact that no systematic ground-water investigations have been made in Brazil, the water-bearing characteristics of the various provinces can be described in only the most general terms. For much of the country, where no data are available, the occurrence of ground water can only be inferred from scanty geologic information and by comparison with similar areas elsewhere. 
The identification and delineation of the ground-water provinces were based on the regional distribution of the dominant geologic units which are known or inferred to have distinctive water-bearing characteristics.

Seven major ground-water provinces (pl. 1) were recognized. On the following pages a brief summary is given of the occurrence of ground water in each. To give the reader a general idea of the characteristics of wells in various parts of the country, miscellaneous information such as well depths, yields, and drawdowns are also given. It should be pointed out that practically all the well data wers obtained from published or unpublished reports, and from the files of the persons mentioned in the introduction to this report.

\section{COASTAL PLAIN PROVINCE}

This province forms a narrow, discontinuous lowland underlain by Cretaceous, Tertiary, and Quaternary strata, consisting largely of clay, sand, gravel, sandstone, and shale. The southernmost segment of the province is composed entirely of Tertiary and Quaternary strata; mostly clay. sand, and gravel.

In the state of Ceará the maximum thickness of the corstal-plain sediments may be about 160 to 200 feet, although in many places in this area they are much thinner. Maack $(1949$, p. 276) reports that a well located in a small segment of the coastal plain (not shown on plate 1) southeast of the city of São Paulo reached Pracambrian gneiss after penetrating about 330 feet of Quaternary strxta. Sanford and Lange (1960, p. 1324) state that the maximum thickness of the Tertiary and Quaternary sediments in the vicinity of the state of Rio Grande do Sul is about 750 feet.

In the eastern part of the state of Bahia and adjacent parts of Sergipe, Alagôas, and Pernambuco, the formations fill a downfaulted basin (graben) in the basement rocks (Link, 1959, p. 12-15). It is interesting to note that in the south half of the basin an oil test well, drilled by Petróleo Brasileiro S.A. (Petrobrás), yielded essentially fresh artesian water from a depth of about 6,100 feet. The well flowed at a rate of about $600 \mathrm{gpm}$ (gallons per minute) and the water contained $340 \mathrm{ppm}$ (parts per million) of chloride and had a temperature of $118^{\circ} \mathbf{F}$. Fresh water was found in another oil test well in this area, at a depth of about 1,030 feet. The well flowed at a rate of about $700 \mathrm{gpm}$ and the water temperature was $93^{\circ} \mathrm{F}$.

Flowing artesian wells have been developed in Pernambuco and, locally, salt water is reported to alternate with zones of fresh water. Salty ground water occurs also in Rio Grande do Sul at shallow depths (50 to 65 feet) but fresh artesian water occurs at about 260 feet below the land surface, under impervious strata. 
In general it is probable that large quantities of ground water can be developed from sand and gravel aquifers in this province.

\section{EASTERN PRECAMBRIAN PROVINCE}

This province is almostly entirely underlain by Precambrian crystalline and metamorphic rocks and its boundary coincides generally with that of the Coastal Brazilian Shield (Jenks, 1956, p. xnI). In the north there are some outliers of Mesozoic (Cretaceous) sedimentary formations. Also, there is a narrow belt of Tertiary and Recent clay and sand extending northeast from the vicinity of the city of São Paulo for more than 100 miles. Alluvial deposits of widely varying thickness and extent occur along many of the river courses thr oughout the province.

In general the Precambrian rocks can be expected to yield only snall supplies of water from joints, crevices, and fault zones. Highly mineralized water occurs in several places in the northern part of the area and, under these conditions, the alluvium may be the onl' source of fresh ground water.

Following are brief descriptions of ground-water conditions and well developments in several states in the province.

Guanabara (city of Rio de Janeiro).-The average yield from more than 200 wells is about $25 \mathrm{gpm}$; average depth is about 250 feet.

$S \tilde{a} o$ Paulo.-The most extensive development of wells in the country is in the vicinity of the city of São Paulo. Leinz and Carvalho (1957, p. $6,7,46,55)$ report that some wells in gneiss and schist in this area yield as much as about $90 \mathrm{gpm}$, although most wells yield about 15 to $20 \mathrm{gpm}$. However, about 25 percent of the wells drilled into the crystalline rocks are dry or produce less than about $5 \mathrm{gpm}$. In general, little water has been obtained from these rocks at depths greater than about 400 feet; most wells have been completed at denths of about 200 to 350 feet. The maximum thickness of the Tertiary and Recent strata overlying the irregular surface on the crystalline rocks is about 650 feet and they consist largely of clay with lenses and layers of sand. Most wells in these strata have been completed at depths of about 70 to 200 feet and yield from about 15 to more than $65 \mathrm{gpm}$. About 35 percent of the wells drilled into these strata are dry or produce less than about $5 \mathrm{gpm}$.

Pernambuco.-The crystalline rocks in parts of this state contain highly mineralized water. For example, waters from 3 wells ranging from about 250 to 350 feet in depth and yielding 10, 30, and $70 \mathrm{gpm}$ respectively, contain about 4,000 to $6,000 \mathrm{ppm}$ of chloride.

The largest of the Mesozoic (Cretaceous) sedimentary outliers (chapadas) in this ground-water province is in the northwestern part of the state and in the adjacent states of Ceará, Piauí, and Paraíba. 
Sternberg $(1956$, p. 216$)$ states that this outlier, called the Chapada do Araripe (pl. 1), "acts as an immense underground storage reservoir." Springs issue from the sides of the chapadas and it is likely that additional water supplies can be developed from wells.

Paraná--In the eastern part of the state some wells in gneiss and granite yield as much as $90 \mathrm{gpm}$. The highest yields are obtained where the granite is coarse grained rather than fine.

Rio Grande do Sul.-Hausman ${ }^{1}$ has prepared a hydrogeologic map indicating that most wells completed in the area of crystalline rocks can be expected to yield less than $15 \mathrm{gpm}$.

The average yield of wells in gneiss and schist may be somewhat higher than the yield from granite. The average thickness of the zone of water-bearing fractures is about 250 to 300 feet.

Minas Gerais.-There is a wide range in the yield of walls completed in crystalline rocks. The maximum yields reported, 210 to 220 gpm, were from several municipal wells in the southeastern part of the state (close to the border of the state of Rio de Janeirc) and in the southwestern part.

Lopes $(1957$, p. 84$)$ presents a table of producing municipal wells in various parts of the state, including many wells in crystalline rocks in the southern and southeastern parts. The average yield of 14 selected wells is $120 \mathrm{gpm}$, with drawdowns ranging from about 30 to 100 feet (average $40 \mathrm{ft}$ ). Depths of these wells range from about 150 to 300 feet and the average is 200 feet.

In the northeastern part of the state, a 65 -foot dug well is completed in alluvium along a river course and yields about $900 \mathrm{gpm}$. However, the water from this well and from another elsewhere along the river contains excessive amounts of iron.

\section{CENTRAL PRECAMBRIAN PROVINCE}

The boundary of this province coincides closely with that of the Central Brazilian Shield (Jenks, 1956, p. xIII). As in the Eastern Precambrian province, water occurs in joints, crevices, and frult zones in crystalline and metamorphic rocks, and well yields are small. In Rondônia Territory, near the Amazon province, the Preambrian rocks are overlain in places by Mesozoic sedimentary strata which may contain aquifers. In the southern part of the state of Pará, between lat $6^{\circ}$ and $10^{\circ} \mathrm{S}$. and long $50^{\circ}$ and $54^{\circ} \mathrm{W}$. there is a large outlier of Cambrian(?) and Ordovician (?) rocks; smaller outliers occur mostly to the south of this area. There is a possibility that these formations include sandstone strata similar to the Cambrian(?) and

\footnotetext{
1 Hausman, Abrão, 1958, Estudo das possibilidades de água subterrânea no Rio Grande do Sul : unpublished manuseript.
} 
Ordovician(?) sandstones in the Amazon province. There also is a fairly large area in the southwest, adjacent to the Paragua! River, where unconsolidated Quaternary strata may yield grounc water. Along the courses of the rivers alluvial deposits may yield more or less ground water, depending in part on the size of the deporits and their hydraulic characteristics.

Following are brief descriptions of ground-water conditions in some of the states in this province, together with miscellaneous information on well developments.

Goias.-In much of the southern part of the state, where most of the water developments are located, it is difficult to obtain adequate supplies of ground water. The average yield of producing wells, most of which are completed in gneiss and schist, is 15 to $20 \mathrm{gpm}$; but many dry holes are drilled. Most wells are completed at depths of about 250 to 350 feet.

Along the Araguaia River, in the northern part of the state, a 2inch driven well in alluvium yields $65 \mathrm{gpm}$.

Mato Grosso.-The average yield of producing wells completed in schist and quartzite in the central and western parts of the state is about $100 \mathrm{gpm}$. Yields are generally larger in topographically low areas; also, most of the water occurs at the contacts of different types of schist or at the contacts of quartzite and schist.

One well in the southwestern part of the state, completed in schist, yields about $100 \mathrm{gpm}$, with a drawdown of about 25 feet. Another in the central part was drilled in schist to about 400 feet and yields about $40 \mathrm{gpm}$.

Minas Gerais.-One well near the western border of the state yields about $90 \mathrm{gpm}$ from quartzite.

\section{NORTHERN PRECAMBRIAN PROVINCE}

This province coincides with the Brazilian part of the Guiana Shield (Jenks, 1956, p. xIII). The occurrence of ground water in the Northern Precambrian province is probably similar to that in the Central Precambrian province.

\section{PARNAIBA-SÃo FRANCISCO MESOZOIC AND PALEOZOIC PRTVINCE}

This province may logically be divided into two areas; the Farnaíba basin in the north, comprising almost all of the states of Maranhão and Piauí and small parts of Ceará, Goiás, and Pará; and the contiguous São Francisco basin in the south, including portion" of the states of Bahia, Goiás, and Minas Gerais.

The Parnaíba sedimentary basin (Kegel, 1955, p. 10) coincides with the so-called Maranhão basin, which has been described by Link (1959, 
p. 8-12). The basin contains alternating beds of Paleozoic and Mesozoic sandstone, silt, and shale, dipping gently toward the center. Some normal faulting has occurred and the fault zones have generally been intruded by diabase dikes.

Kegel $(1955$, p. 9, 59) describes the following sandstone aquifers in order of increasing yield. In addition to the Mesozoic aquifers mentioned below, some water may be available locally in C'etaceous sandstones (Oliveira, 1956, p. 47 ; Link, 1959, p. 10).

\begin{tabular}{|c|c|c|c|}
\hline Name & Age & \multicolumn{2}{|c|}{$\begin{array}{l}\text { Appriximate thick- } \\
\text { ness (feet) }\end{array}$} \\
\hline Sambaíba Formation & Triassic $(?)$ & 150 & $-200(?)$ \\
\hline Motuca Formation & Triassic(?) & 150 & -350 \\
\hline Piauí Formation & late Carboniferous & 150 & -650 \\
\hline Poti Formation & early Carboniferous & 650 & -800 \\
\hline $\begin{array}{l}\text { Saraiva Member of Pedra de Fogo For- } \\
\text { mation. }\end{array}$ & Permian & 200 & $-350^{\prime}$ \\
\hline Oeiras Member of Cabeças Formation & Middle Devonian_..- & 650 & $-1,000^{1}$ \\
\hline Itaim Member of Pimenteira Formation. & Early Devonian & 500 & $-1,000^{\imath}$ \\
\hline Serra Grande Formation & Early Devonian.... & 150 & $-2,300$ \\
\hline
\end{tabular}

1 Thickness of entire formation.

Excellent artesian conditions prevail in much of the Parnaiba basin and there are numerous flowing wells.

The southern part of the province, essentially the São Francisco basin, is underlain by Cretaceous, Triassic, and Silurian fcrmations (Lamego, 1960). The Silurian includes slate and limestone aquifers which yield water from fractures and solution cavities (Oliveira 1956, p. 23, 54). Although solution cavities have been reported only locally in the Silurian limestones, they probably occur in many parts of the São Francisco basin. The Cretaceous and Triassic formations include sandstones that are presumed to be water bearing.

Along the São Francisco River ground water also may be developed from the alluvium, although in several places the water has been reported to contain excessive amounts of iron.

In the northwestern part of the province there are a few areas where Precambrian basement rocks are exposed at land surface.

Following are brief descriptions of ground-water conditions in several of the states in the province, together with miscellaneous information on well developments.

Goiás.-In the northeastern part of the state a well about 425 feet deep yields $20 \mathrm{gpm}$.

Maranhão.-Petrobrás drilled a dry oil test well in the southwestern part of the state to a depth of 3,835 feet, at which depth it flowed fresh water at a rate of about $1,100 \mathrm{gpm}$. The pressure at the land surface was 64 pounds per square inch and the water tempersture was $100^{\circ} \mathrm{F}$. According to $\operatorname{Link}(1959$, p. 12) the well penetrated sand- 
stones of the Cabeças Formation (Middle Devonian). It was completed as a municipal water well at a depth of about 1,950 feet.

Minas Gerais.-Well yields from Silurian aquifers are generally highest in valleys and on flood plains. Locally the limestones contain solution cavities.

In the northern part of the state 7 supply wells in 1 mur icipality were completed in Silurian aquifers at depths of about 250 to 400 feet; yields range from 20 to $40 \mathrm{gpm}$ and drawdowns from 7 to about 230 feet. In another municipality in this part of the state 3 wells, about 200 feet deep, each produce about $75 \mathrm{gpm}$ from Silurian aquifers.

Six producing wells selected from Lopes' table (1957, p. 84), and presumed to be completed in Silurian formations, range in depth from about 100 to 360 feet and yield about 75 to $200 \mathrm{gpm}$; drawdowns range from about 3 to 65 feet. The wells are located in tho central and western parts of the state.

The maximum thickness of the alluvium along the São Francisco River is about 100 feet. Ten wells in these deposits yield water containing excessive amounts of iron.

Piaui.-Numerous flowing artesian wells have been developed in the central and northern parts of the state. Three wells in th northeast, completed at an average depth of about 100 feet, flow at a rate of about $25 \mathrm{gpm}$ each. The wells were completed in the Itaim Member of the Pimenteira Formation (Kegel, 1955, p. 47). In tl a northwest, 5 wells ranging in depth from 985 to 1,742 feet, tap Carboniferous and Middle Devonian sandstones; rates of flow range from 8 to about $65 \mathrm{gpm}$ (Kegel, 1955, p. 27-33).

Regarding the quality of the water, Kegel $(1955$, p. 58) reports that shallow ground waters in the state usually are more mineralized than deep waters, though in general they are all potable.

\section{PARANÁ MESOZOIC AND PALEOZOIC PROVINCE}

This province consists of a relatively small northern segment, underlain largely by Mesozoic formations; small areas in the extreme northern part of this segment are underlain by Cambrian(?) and Ordovician(?) formations. A much larger southern segment concidos rather closely with the Paraná geosynclinal basin (Taylor, 1952, p. 1613; Sanford and Lange, 1960 , p. 1318), which contains rock formations that range in age from early Paleozoic to Late Cretaceous (Oliveira, 1956, p. 18, 40).

Following are the most important Mesozoic aquifers in the southern segment of the province. The indicated thicknesses are given in part by Link $(1959$, p. 6) and by Sanford and Lange (1960, p. 1324) for the entire basin. 


\begin{tabular}{|c|c|c|c|}
\hline Name & Age & $\begin{array}{c}\text { Approximate } \\
\text { thickness (feet) }\end{array}$ & Remarks \\
\hline Baurú Sandstone... & $\begin{array}{l}\text { Late } \\
\text { Cretaceous. }\end{array}$ & $0-700$ & $\begin{array}{l}\text { Occurs only in northern } \\
\text { part of basin. }\end{array}$ \\
\hline Caiuá Sandstone.... & Jurassic _...... & $0-800$ & Do. \\
\hline Serra Geral Lavas. - & Late Triassic...- & $800-5,100$ & $\begin{array}{l}\text { Interbedded with thin } \\
\text { layers and lenses of } \\
\text { sandstone. }\end{array}$ \\
\hline $\begin{array}{l}\text { Botucatú } \\
\text { Sandstone. }\end{array}$ & Triassic $\ldots \ldots$ & $150-1,700$ & - n \\
\hline $\begin{array}{l}\text { Santa Maria } \\
\text { Sandstone. }\end{array}$ & Triassic ....... & $0-650$ & $\begin{array}{l}\text { Occurs only in Rio Grande } \\
\text { do Sul. }\end{array}$ \\
\hline
\end{tabular}

Paleozoic aquifers in the southern segment of the province are known to be of significance only along the eastern and southeastern margins of the area and in the northwestern part. They include Permian sandstones (Passa Dois Series); Carboniferous sandstones and conglomerates (Tubarão Series), some of which are of glacial origin; and Devonian, Silurian, and Cambrian(?) and Ordovician(?) sandstones of limited areal extent (Oliveira, 1956, p. 21-35; Lamego, $1960)$.

In the northern segment of the province, thick sandstones of Cretaceous (?) age are presumed to be water bearing. Locally, as in central Mato Grosso, they form dissected plateaus.

It is likely that ground water can be developed in many places from alluvial deposits along the river courses.

Following are brief descriptions of ground-water conditions in several states in the province, together with miscellaneous infc"mation on well developments.

Goiás.-Two wells in the southern part of the state, tapping basalt. at a depth of about 200 feet, yield about $80 \mathrm{gpm}$ each.

Mato Grosso (southern part).-A flow of about $50 \mathrm{gpm}$ has been obtained from a well in sandstone of Mesozoic age. Yields of about 45 to $65 \mathrm{gpm}$ are obtained from sandstone of Mesozoic age by 3 wells, 1 of which is about 330 feet deep and 2 are about 690 feet deep.

Each of 2 wells completed in basalt yields about $200 \mathrm{gpm}$.

Minas Gerais.-Two wells completed in Serra Geral basalt that is overlain by sandstone yield about $100 \mathrm{gpm}$ each. A group of 31 wells at one municipality was completed in sandstone of Mesozoic age; yields range from about 15 to $80 \mathrm{gpm}$ and average about $55 \mathrm{gpm}$. Lopes $(1957$, p. 84) gives records of 3 wells at different municipalities, obtaining water from sandstone of Mesozoic age at depths of abort 170 to 200 feet. The yields are 75,90 , and $175 \mathrm{gpm}$ and drawdowns range from 20 to 35 feet.

Paraná.-The best aquifer in the state is the Botucatú Sandstone, which is usually found at the base of the Serra Geral Lavas. 
Next in importance to the Botucatú Sandstone as a source of ground water are the Serra Geral Lavas. Wells obtain water largely from the interflow zones and joints; also from sandstone layers between the lava beds. A group of 9 farm and industrial wells in the wostern part of the state yield from 35 to $100 \mathrm{gpm}$ (average $70 \mathrm{gpm}$ ) with drawdowns ranging from 5 to 130 feet; depths range from 145 to 390 feet (average $230 \mathrm{ft}$ ).

Wells in the Caiua Sandstone usually yield more than about 45 gpm and, occasionally, yields of as much as $260 \mathrm{gpm}$ are obtained.

Although the distribution of Carboniferous sandstones is irregular, yields of as much as 45 to $55 \mathrm{gpm}$ have been obtained.

Rio Grande do Sul.-The following table gives the average yields that may be expected from the significant aquifers in the state. The information has been modified from a report by Hausman (1958).

\begin{tabular}{|c|c|}
\hline Aquifer & Yield $(g \mathrm{pm})$ \\
\hline Alluvium _... & $45-90$ \\
\hline
\end{tabular}

Botucatú Sandstone and underlying

Santa Maria

Sandstone.

Tubarão Series (sandstone).

Devonian, Silurian, and Cambrian(?) and Ordovician(?) sandstones. of State) $>90$ of State) $45-90$

$15-45$
Remarks

Along river courses.

There are two linear intersecting zones, crossing the northern and central parts of the state, where fractures and joints are more numerous and wells may yield 45 to $90 \mathrm{gpm}$.

In the southwest a 330 -ft well yields about $500 \mathrm{gpm}$. Yields are higher where water is confined by orerlying lava beds.

(Eastern part

(Western part
Strata dip north and northwest. Water is under artesian pressure and is mineralized in places.
In places sandstone beds are mcre than $300 \mathrm{ft}$ thick.

São Paulo.-The average yield of wells tapping the Baurú Sandstone, which occurs in the western part of the state, is about 90 to 130 gpm. Two wells at one municipality each produces more than about $300 \mathrm{gpm}$. The sandstone is fairly well cemented and the water is usually relatively hard and mineralized.

Yields of wells in the Serra Geral Lavas average about $90 \mathrm{gpm}$.

The Botucatú Sandstone is generally soft, poorly cemented, and about 300 feet thick. It contains relatively soft artesian water confined by the overlying lava beds. In the northern part of the state wells at two municipalities yield about $300 \mathrm{gpm}$ and more than 500 gpm respectively; at another a flow of $60 \mathrm{gpm}$ has been obtained. 
Sandstone beds in the Tubarão Series are irregularly distributed and, locally, some wells yield as much as 130 to $200 \mathrm{gpm}$. In places, where diabase dikes have intruded the sandstones, ground-rater dams occur and good supplies of ground water may be developed. Also, considerable quantities of ground water are found at the base of the glacial deposits in contact with the underlying crystalline rocks.

\section{AMAZON PROVINCE}

This province coincides with the known extent of the Amazon geosyncline (Lower Amazon River basin) and the broad flat area of the Upper Amazon basin. The geosyncline has been filled to a great but unknown depth, largely with Paleozoic and Cenozoic (Tertiary) formations; Mesozoic formations are known to occur only locally. The Paleozoic formations crop out in long narrow areas on botl the north and the south sides of the Lower Amazon basin, and they include some thick Carboniferous, Devonian, Silurian, and Cambrian(?) and Ordovician (?) sandstones; some of the Tertiary formations also are composed of sandstone (Jenks, 1956, p. xIIr. xIv ; Oliveira, 1956, p. 1, 46, $56)$. Although most of the Paleozoic sandstones have beer described as fine grained, it is possible that some may yield significant supplies of ground water.

In most of the province the surface is composed of Cenozoic sediments; where ground water has been needed, these sediments have been tapped by shallow wells in the vicinity of the rivers.

At Belém, near the mouth of the Amazon, wells about 130 to 200 feet deep have been jetted into alluvium. In one municipality in the western part of the state of Pará, near the Amazon River, the maximum depth of wells is about 230 feet.

One of the most common types of ground-water developments along the Amazon in Pará is the so-called Amazon-type well. A perforated concrete and brick casing is constructed on the ground in a circle about. 15 feet in diameter. The well is dug inside the casing which gradually settles. When the water table is reached, sand and other fine-grained materials are usually jetted out, but occasionally a "clam-sholl" bucket is used. If coarse material is encountered which prevents the casing from settling or which cannot be jetted out, a man in a diring suit is lowered into the well to dig. Wells of this type have yielded as much as 400 to $800 \mathrm{gpm}$.

\section{GROUND-WATER PROBLEMS}

It is very difficult to obtain large or even adequate grc'nd-water supplies in many areas of Brazil because of the widespread distribution of Precambrian crystalline rocks, which contain water only in 
crevices, joints, and fault zones. It may be possible to develop wells with somewhat larger yields by making detailed studies of well records, the occurrence of joints and faults, and their relation to the topography, drainage, and direction of ground-water movement. Also, it is more than likely that a relation exists between the rock type and the magnitude of well yield. In general it is probable that wells in topographically low areas in the Precambrian rocks would have larger yields than those on the high areas, as the low areas commonly mark zones of strong joints or fissures, and the water would be under a higher head with respect to the surrounding land surface.

To a certain extent the problem of low yields applies to those parts of the Paraná Mesozoic and Paleozoic province where the Serra Geral Lavas occur. Where the lavas are very thick and they do not yield sufficient water, it is prohibitively expensive to drill through them to obtain water from the underlying sandstones. This condition is prevalent in the northern part of the state of Rio Grande do Sul and probably in other areas also.

\section{NORTHEAST BRAZIL}

As was indicated above in the section entitled "Geography," parts of northeast Brazil are frequently subjected to floods and dronghts. The region lies largely in the Eastern Precambrian and the ParmaíbaSão Francisco Mesozoic and Paleozoic provinces and it includes parts of the states of Piauí, Ceará, Rio Grande do Norte, Paraíba, Pernambuco, Alagôas, Sergipe, and Bahia. It covers about 342,000 square miles, an area larger than the state of Texas (267,340 sq mi) (Gorton, 1959$, p. 6$)$.

In addition to the general difficulty in developing large groundwater supplies in the sections underlain by Precambrian crystalline rocks, the water-supply problem is complicated in some areas by the occurrence of highly mineralized water. Another adverse condition in the section that lies in the Eastern Precambrian province is the relatively thin residual mantle of weathered material. Owing to tha generally impervious character of the underlying rocks and the toriential nature of the rains, the rate of surface-water runoff is high and there is a minimum opportunity for infiltration. In developing water supplies in this area, particular attention should be given to the following factors: (a) the average thickness of the zone of water-bearing fractures in crystalline rocks; that is, the depth below which it would be uneconomical to drill for water; (b) the occurrence of shallow ground water in the alluvium, and particularly of surface-water bodies, offering the possibility of inducing infiltration by wells or infiltration galleries; and (c) the availability of water in the sedimentary formations that form the chapadas. 


\section{SÃo PAULO AREA}

The urban area of São Paulo, in the Eastern Precambrian province, is the most heavily populated and industrialized area in the country and is expanding rapidly. As noted earlier, most ground water is obtained from discontinuous bodies of sand of Tertiary age, and from fractures and joints in the Precambrian rocks (Leinz and Carvalho, 1957, p. 42). Dr. Viktor Leinz estimates roughly that thers may be as many as 1,500 private and industrial wells in the area (personal communication, April 19, 1960). Undoubtedly some interference occurs between wells as a result of the intensity of the ground-water development in this area; however, the degree of seriousness of this condition is unknown. In addition, the absence of specific data on the total quantity of water pumped, the extent to which water levels have declined, the hydraulic characteristics of the water-bearing formations, or the occurrence of natural or induced recharge makes it impossible to assess the problem adequately.

\section{SELECTED REFERENCES}

Gorton, W. W., 1959, The northeast of Brazil-economic information on a problem area: U.S. Operations Mission to Brazil, mimeographed rept., $36 \mathrm{p}$.

James, P. E., 1950, Latin America: The New York, Odyssey Press, 848 p.

Jenks, W. F., 1956, Handbook of South American geology, an explanation of the geologic map of South America: Geol. Soc. America Mem. 65, $378 \mathrm{p}$.

Kegel, Wilhelm, 1955 Água subterrânea no Piaû́: Brazil Div. Geol. e Min. Bol, $156,61 \mathrm{p}$.

Lamego, A. R., 1960, Mapa geológico do Brasil : Departamento Nac'onal da Produção Mineral, Divisão de Geologia e Mineralogia.

Leinz, Viktor, and Carvalho, Anna Maria Vieira de, 1957, Contril'ição à geologia da bacia de São Paulo: Univ. São Paulo, Faculdade de F'losofia, Ciências, e Letras, Bol. 205, 61 p.

Link, W. K., 1959, The sedimentary framework of Brazil: Wor'd Petroleum Congress, 5th, Sec. 1, paper 50, $19 \mathrm{p}$.

Lopes, Jasé de Carvalho, 1957, Hidrogeologia e aspectos Brasileiros da sua aplicação: Belo Horizonte, Minas Gerais, Optim!ıs Studio Ltda.

Maack, Reinhard, 1949, Espessura e sequência dos sedimentos Quaternários no litoral do Estado do Paraná: Instituto de Biologia e Pescuisas Tecnológicas, Estado do Paraná, Arquivos de Biologia e Tecnologia, v. 4, art. 19, p. 271-286.

Oliveira, A. I. de, 1956, Brazil, in Jenks, W. F., Handbook of South American geology, an explanation of the geologic map of South America: Geol. Soc. America Mem. 65, p. 1-62.

Oliveira, A. I. de, and Leonardos, O. H., 1943, Geologia do Brasil; 2nd Ed.: Brasil, Min. da Agricultura, Ser. Didática, no. 2, 813 p., Rio de Janeiro.

Sanford, R. M., and Lange, F. W., 1960, Basin-study approach to oil evaluation of Paraná miogeosyncline, south Brazil: Bull. Am. Assoc. Petroleum Geologists, v. 44, no. 8, p. 1316-1370.

Serra, Adelberto, 1955, Atlas climatológico do Brasil: Conselho de Geografia e Serviço de Meteorologia, v. 1. 


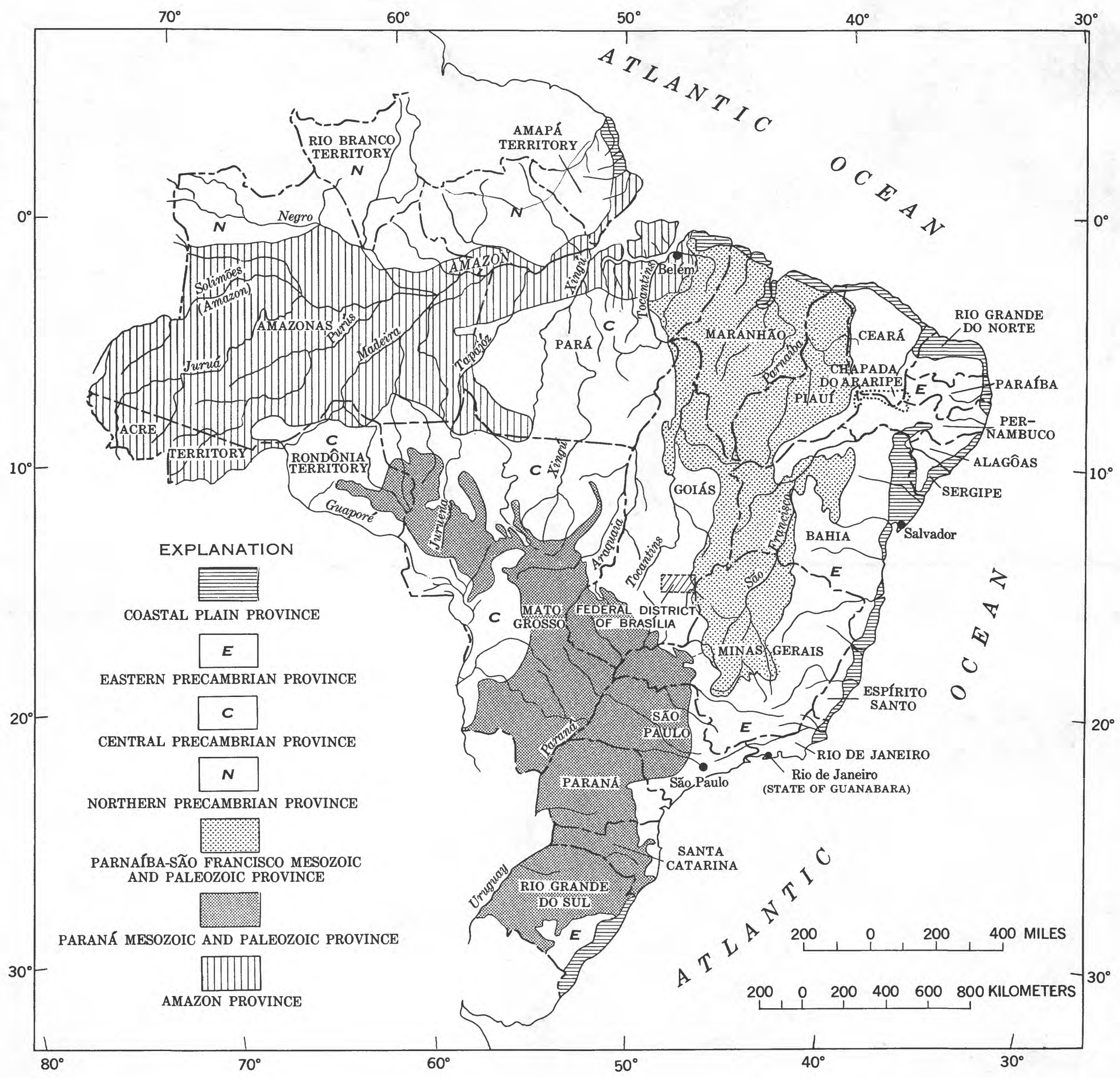

MAP OF BRAZIL SHOWING GROUND-WATER PROVINCES 